\title{
Ventilator-Associated Pneumonia (VAP)
}

\section{Mona Z Zaghloul}

Microbiology Unit, Department of Clinical Pathology, Ain Shams University Hospitals, Cairo, Egypt

*Corresponding author: Zaghloul MZ, Ain Shams University Hospitals, Cairo, Egypt, Tel: 02-24023494; E-mail: monazaki_810@hotmail.com

Received date: October 21, 2015, Accepted date: October 26, 2015, Published date: October 30, 2015

Copyright: (c) 2015 Zaghloul MZ. This is an open-access article distributed under the terms of the Creative Commons Attribution License, which permits unrestricted use, distribution, and reproduction in any medium, provided the original author and source are credited.

\section{Editorial}

Ventilator-associated pneumonia (VAP) is a pulmonary infection that occurs more than 48 hours after patients have been intubated and received mechanical ventilation. The incidence of VAP ranges from 6 to $52 \%$ and can reach $76 \%$ in some specific settings [1]. The incidence depends on several factors, the duration of mechanical ventilation, reintubation, supine position, advanced age and altered consciousness. The VAP group was classified into two groups, early-onset type (within 48-96 h) and late-onset type ( $>96 \mathrm{~h}$ ) [2].

Ventilator-associated bacterial pneumonia is an important intensive care unit (ICU) acquired infection in mechanically ventilated patients. Early and correct diagnosis of VAP is difficult but is an urgent challenge for an optimal antibiotic treatment [3]. Diagnosing VAP requires a high clinical suspicion combined with bedside examination, radiographic examination, and microbiologic analysis of respiratory secretions. Pugin et al., [4] developed a composite clinical score, called the clinical pulmonary infection score (CPIS), based on six criteria: temperature, blood leukocyte count, volume and purulence of tracheal secretions, oxygenation, pulmonary radiography, and semiquantitative culture of tracheal aspirate. The score varied from 0 to 12 . A CPIS of $>6$ had a sensitivity of $93 \%$ and a specificity of $100 \%$. Samples from the respiratory tract were collected by bronchoscopy from pneumonic cases for quantitative microbiological examination in a specific, constant sequence and with the following thresholds: tracheobronchial secretion, $10^{5}$ and $10^{6}$ colony-forming units $\left.(\mathrm{CFU}) / \mathrm{ml}\right)$; protected specimen brush, $10^{3} \mathrm{CFU} / \mathrm{ml}$ and bronchoalveolar lavage, $10^{4} \mathrm{CFU} / \mathrm{ml}$ [3].

For respiratory infection to occur, at least one of the three following factors must be present, immunodeficiency in the host, an inoculum of microorganisms into the lower respiratory tract that is large enough to overwhelm the host's immune system, or a highly virulent organism. Many ICU patients have prevalent underlying factors associated with immunodeficiency, such as diabetes mellitus or glucocorticoid therapy; these factors increase the risk of infection [5]. The organisms recovered have an impact on outcome, with higher mortality rates seen in VAP caused by Pseudomonas aeruginosa, Acinetobacter baumannii and Stenotrophomonas maltophilia [6].

Montero et al., [7] reported imipenem as a drug of choice unless there is a very high level of carbapenems resistance. Rifampins are used either as monotherapy or in combination with imipenem or tobramycin against highly carbapenem-resistant Acinetobacter strains; colistin had little effect either singly or in combination with rifampin in vitro. Ampicillin/sulbactam and cilastin/imipenem have equivalent efficacy for Acinetobacter spp. Intravenous colistin therapy has better results in patients with multidrug resistant Acinetobacter spp. and Pseudomonas spp.
The mortality attributable to VAP has been reported to range between 0 and $50 \%$ [8-10]. However, it is not certain that pneumonia is responsible for death or whether fatal outcome is caused by other risk factors for death that exist before the onset of pneumonia [11]. Simple and effective preventive measures for VAP might include noninvasive mechanical ventilation, diligent respiratory care, hand hygiene, elevation of head, oral instead of nasal cannulation, minimization of sedation, institution of weaning protocols, proper antibiotics administration according to semiquantitative culture and antibiogram for respiratory secretions [12].

\section{References}

1. Koenig SM, Truwit JD (2006) Ventilator-associated pneumonia: diagnosis, treatment, and prevention. Clin Microbiol Rev 19: 637-657.

2. Gadani H, Vyas A, Kar AK (2010) A study of ventilator-associated pneumonia: Incidence, outcome, risk factors and measures to be taken for prevention. Indian J Anaesth 54: 535-540.

3. Woske HJ, Röding T, Schulz I, Lode H (2001) Ventilator-associated pneumonia in a surgical intensive care unit: epidemiology, etiology and comparison of three bronchoscopic methods for microbiological specimen sampling. Crit Care 5: 167-173.

4. Pugin J, Auckenthaler R, Mili N, Janssens JP, Lew PD, Suter PM Diagnosis of ventilatorassociated pneumonia by bacteriologic analysis of bronchoscopic and nonbronchoscopic "blind" bronchoalveolar lavage fluid. Am Rev Respir Dis. 1991 May; 143(5 Pt 1):1121-9.

5. Lambotte O, Timsit JF, Garrouste-Orgeas M, Misset B, Benali A, et al. (2002) The significance of distal bronchial samples with commensals in ventilator-associated pneumonia: colonizer or pathogen? Chest 122: 1389-1399.

6. Kappstein I, Schulgen G, Beyer U, Geiger K, Schumacher M, et al. (1992) Prolongation of hospital stay and extra costs due to ventilator-associated pneumonia in an intensive care unit. Eur J Clin Microbiol Infect Dis 11: 504-508.

7. Montero A, Ariza J, Corbella X, Doménech A, Cabellos C, et al. (2004) Antibiotic combinations for serious infections caused by carbapenemresistant Acinetobacter baumannii in a mouse pneumonia model. J Antimicrob Chemother 54: 1085-91.

8. Charles MP, Kali A, Easow JM, Joseph NM, Ravishankar M, et al. (2014) Ventilator-associated pneumonia. Australas Med J 7: 334-344.

9. Cunnion KM, Weber DJ, Broadhead WE, Hanson LC, Pieper CF, et al. (1996) Risk factors for nosocomial pneumonia: comparing adult criticalcare populations. Am J Respir Crit Care Med 153: 158-162.

10. Bregeon F, Ciais V, Carret V, Gregoire R, Saux P, et al. (2001) Is ventilatorassociated pneumonia an independent risk factor for death? Anesthesiology 94: 554-560.

11. Kollef MH, Silver P, Murphy DM, Trovillion E (1995) The effect of lateonset ventilator-associated pneumonia in determining patient mortality. Chest 108: 1655-1662.

12. Koenig SM, Truwit JD (2006) Ventilator-associated pneumonia: diagnosis, treatment, and prevention. Clin Microbiol Rev 19: 637-657. 